\title{
Major changes in glacial and Holocene terrestrial temperatures and sources of organic carbon recorded in the Amazon fan by tetraether lipids
}

\author{
James A. Bendle \\ Organic Geochemistry Unit, Bristol Biogeochemistry Research Centre, School of Chemistry, \\ University of Bristol, Bristol BS8 1TS, UK \\ Now at Glasgow Molecular Organic Geochemistry Laboratory, Department of Geographical and Earth \\ Sciences, University of Glasgow, Glasgow G12 8QQ, UK (james.bendle@ges.gla.ac.uk)
}

\section{Johan W. H. Weijers}

Department of Marine Organic Geochemistry, Royal Netherlands Institute for Sea Research, NL-1790 $A B$ Den Burg, Netherlands

Now at Department of Earth Sciences-Geochemistry, Utrecht University, NL-3508 TA Utrecht, Netherlands

\section{Mark A. Maslin}

Environmental Change Research Centre, Department of Geography, University College London, London WC1E 6BT, UK

\section{Jaap S. Sinninghe Damsté, Stefan Schouten, and Ellen C. Hopmans} Department of Marine Organic Geochemistry, Royal Netherlands Institute for Sea Research, NL-1790 AB Den Burg, Netherlands

\section{Christopher S. Boot and Richard D. Pancost Organic Geochemistry Unit, Bristol Biogeochemistry Research Centre, School of Chemistry, University of Bristol, Bristol BS8 1TS, UK}

[1] The Amazon basin is a major component of the global carbon and hydrological cycles, a significant natural source of methane, and home to remarkable biodiversity and endemism. Reconstructing past climate changes in the Amazon basin is important for a better understanding of the effect of such changes on these critical functions of the basin. Using a novel biomarker proxy, based on the membrane lipids of soil bacteria with a new regional calibration, we present a reconstruction of changes in mean annual air temperatures for the Amazon catchment during the last 37 kyr B.P. Biomarkers were extracted from Ocean Drilling Program sediment core ODP942 recovered from the Amazon fan. The Amazon fan is a major depository for terrestrial sediments, with the advantage that the terrestrial material captured reflects a regional integration of the whole river catchment. The reconstructed tropical Amazonian temperatures were $\sim 5^{\circ} \mathrm{C}$ cooler at the Last Glacial Maximum $\left(\sim 21^{\circ} \mathrm{C}\right)$ compared to modern values $\left(\sim 26^{\circ} \mathrm{C}\right)$. This is in agreement with previous estimates of tropical continental temperatures in the tropical Amazon basin and tropical Africa during the Last Glacial Maximum. Moreover, we also illustrate how the soil bacterial membrane lipid record reveals major changes in basin dynamics and sediment provenance during the glacial-Holocene transition, impacting the biomarker reconstructions from $\sim 11 \mathrm{kyr}$ onward. 
Components: 7300 words, 5 figures, 1 table.

Keywords: Amazon; glacial maximum; Holocene; lipids; tetraethers; temperature.

Index Terms: 0473 Biogeosciences: Paleoclimatology and paleoceanography (3344, 4900); 1055 Geochemistry: Organic and biogenic geochemistry; 4914 Paleoceanography: Continental climate records.

Received 26 July 2010; Revised 9 September 2010; Accepted 15 October 2010; Published 15 December 2010.

Bendle, J. A., J. W. H. Weijers, M. A. Maslin, J. S. Sinninghe Damsté, S. Schouten, E. C. Hopmans, C. S. Boot, and R. D. Pancost (2010), Major changes in glacial and Holocene terrestrial temperatures and sources of organic carbon recorded in the Amazon fan by tetraether lipids, Geochem. Geophys. Geosyst., 11, Q12007, doi:10.1029/2010GC003308.

\section{Introduction}

[2] Reconstructing Amazon basin paleoclimatic change is important for a number of reasons. The region is a major component of the global carbon cycle, producing $\sim 20 \mathrm{Pg}$ C/year by photosynthesis [Roy et al., 2001] accounting for $\sim 20 \%$ of terrestrial carbon cycling and respiration and holding $\sim 25 \%$ of terrestrial biomass [Malhi et al., 2002]. It is also a principle component in the global hydrological cycle; when the Amazon flows into the Atlantic it is carrying $\sim 20 \%$ of all river water discharged into the global oceans [Franzinelli and Potter, 1983]. Moreover, a large proportion of water is recycled in the basin through the precipitation/evaporation cycle [Salati and Nobre, 1991]; the associated evapotranspiration vents latent heat into the atmosphere, contributing to the largest and most intense land-based atmospheric convection center on Earth with connections to extratropical hydrology and circulation [e.g., Flood et al., 1995; Grimm and Silvia Dias, 1995; Marengo and Nobre, 2001; Rao and Hada, 1990]. It has been suggested that on millennial time scales, the region may have been pivotal in propagating major climate events between hemispheres [Ettwein, 2005; Maslin and Burns, 2000]. Finally, it is essential to understand Amazon climatic change as a potential driver of the remarkable biodiversity and endemism of the region [Morley, 2000; Willis and McElwain, 2002], e.g., to test the tropical rain forest refuge [e.g., Haffer, 1969; Haffer and Prance, 2001], the rain forest canopy density [Cowling et al., 2001] and the precessional-forced seasonality hypotheses [Maslin et al., 2005].

[3] Molecular biomarkers have become an increasingly common tool in the reconstruction of terrestrial climate, past vegetation assemblages and environmental conditions [e.g., Pancost and Boot, 2004]. One efficacious approach is to obtain continuous and high-resolution terrestrial environmental records from marine sediments. Rivers and wind transport large amounts of terrestrial organic material to the oceans, of which a fraction is sequestered and preserved in marine sediments [Hedges et al., 1997]. Deep-sea fans, such as the Amazon fan, are a major depository for terrestrial sediments [Flood and Piper, 1997]. In fact, biomarkers of unambiguous terrestrial origin (e.g., high molecular weight $n$-alkanes, $n$-alkanols, pentacyclic triterpenoids, including taraxerol) dominate in the marine sediments of the Amazon fan and at our study site (Ocean Drilling Program Site 942, Figure 1) [Boot et al., 2006; Hinrichs and Rullkötter, 1997]. A particular advantage of this approach is that the terrestrial material captured by the marine archives reflects a regional integration of the terrestrial ecology [Traverse, 1989].

[4] Glycerol dialkyl glycerol tetraethers (GDGTs) with branched alkyl chains (I-III in Figure 2) are ubiquitous in peat [Sinninghe Damsté et al., 2000], soils [Weijers et al., 2006b, 2007b] and coastal marine sediments [Hopmans et al., 2004]. In the latter setting they derive from river-transported soil organic matter [Herfort et al., 2006; Hopmans et al., 2004; Kim et al., 2008, 2010; Sinninghe Damsté et al., 2000]. Stuctural characterization of the branched GDGTs indicates that bacteria and not archaea are the producers of these lipids [Weijers et al., 2006a]. Weijers et al. [2007b], found that temperature and soil $\mathrm{pH}$ are the two main environmental parameters that control the distribution of branched GDGT membrane lipids in a set of globally distributed soils. Specifically, the degree of cyclization of the branched GDGTs, expressed in the cyclization ratio of branched GDGTs (CBT), correlates well with soil $\mathrm{pH}$, whereas the degree of methylation, expressed in the methylation index of branched GDGTs (MBT), depends on both soil pH and annual mean air temperature (MAT). These new paleoenvironmental proxies have been successfully applied in reconstructions of temperature changes during the glacial to Holocene transition in 


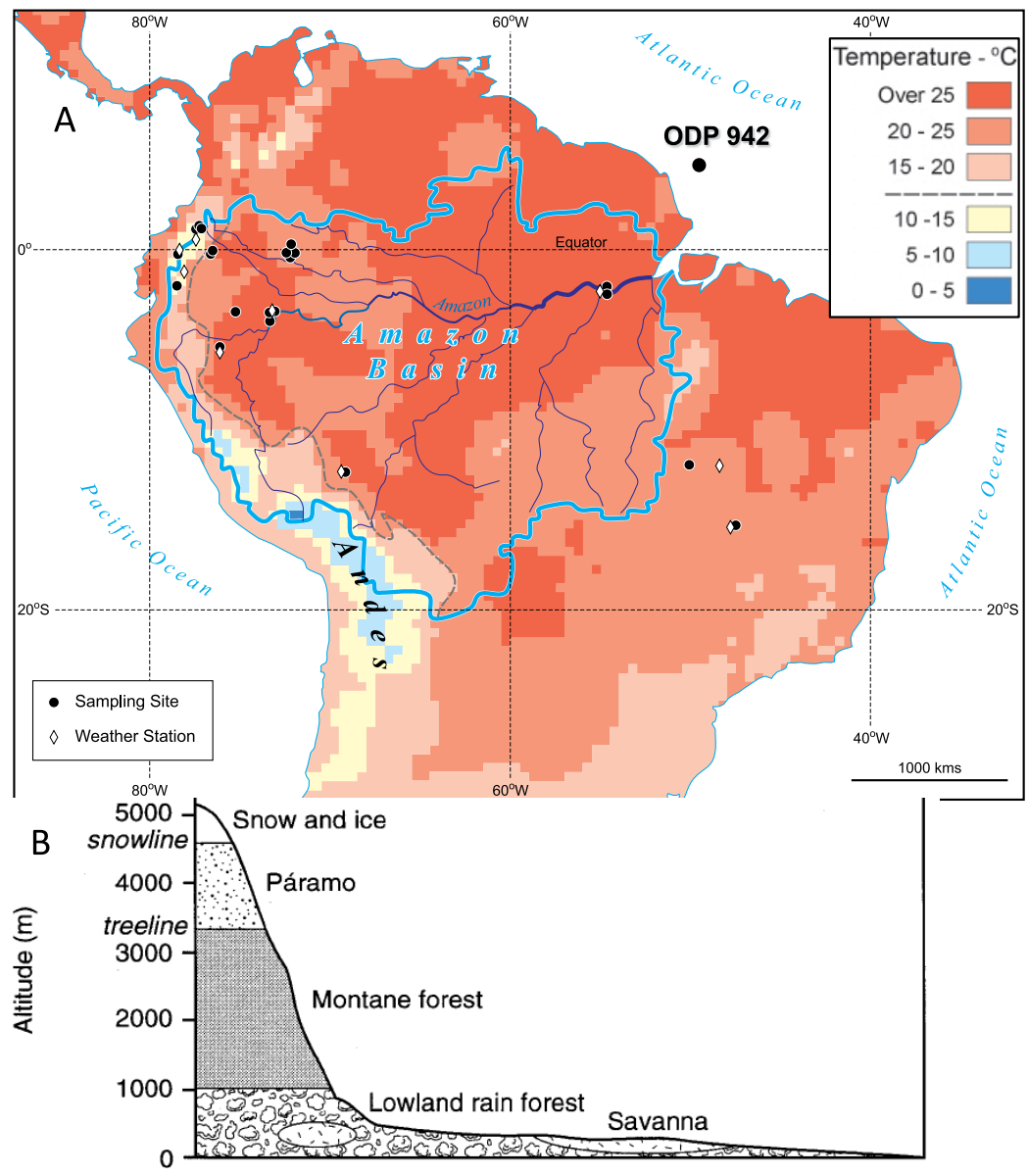

Figure 1. (a) Annual mean air temperature map of the Amazon region showing the physical outline of the Amazon basin catchment area, main river channels, the location of ODP Site 942, and the locations of soil samples and weather stations used in the new regional Amazon MBT/CBT calibration (see Table 1 for details). Soil samples were collected from the World Soil Database collection of the International Soil Research and Information Centre (ISRIC) in Wageningen, Netherlands. The South American mean annual air temperature map is derived from Legates and Willmott [1990] and is in ASCIIGRID format, referenced to a geographic coordinate system and reconstituted graphically into Arc/Info software. (b) Schematic cross section of the equatorial Andes and Amazon basin showing the present distribution of the vegetation belts (after Haberle and Maslin [1999], adapted from Hooghiemstra [1984]).

the Congo basin [Weijers et al., 2007a] and the Eocene-Oligocene transition in Greenland [Schouten et al., 2008]. Further validation is found in a strong temperature dependence of the branched GDGT distribution in geothermally heated soils [Peterse et al., $2009 \mathrm{~b}]$ and in altitudinal $(1700-3300 \mathrm{~m})$ transects on Mt. Kilimanjaro, Tanzania and Mt. Gongga (China) [Peterse et al., 2009c; Sinninghe Damsté et al., 2008]. A recent study of branched GDGTs in marine sediments from the Skagerrak revealed a strong relationship of MBT/CBT-derived temperature with summer air temperatures [Rueda et al., 2009].

[5] Additionally, insights into changes in terrestrial sediment supply to the marine environment can be gained from the branched versus isoprenoid tetraether (BIT) index, a proxy for the relative fluvial input of terrestrial organic matter (TOM) in the marine environment [Hopmans et al., 2004].

[6] This paper presents a new MBT/CBT-derived estimate of regionally integrated annual MAT, for the central/eastern Amazon basin during the last glacial period. However, we also illustrate, using tetraether and inorganic geochemical parameters, how major changes in sediment provenance during the glacial-Holocene transition impact the GDGTbased MAT reconstructions.

\section{Methods}

\subsection{Site Description and Age Model}

[7] The Amazon Fan is the third largest submarine delta, situated off the northeastern coast of Brazil. 


\section{Branched GDGTs}
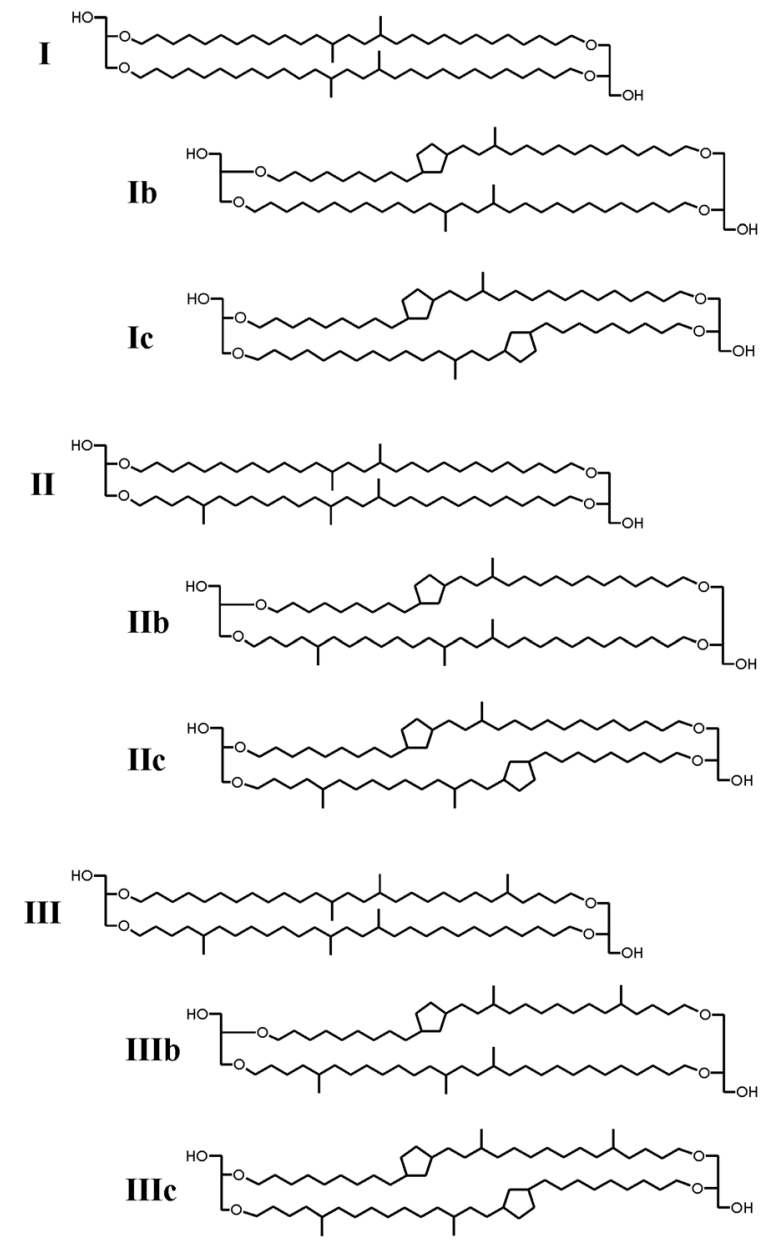

\section{Isoprenoidal GDGT}

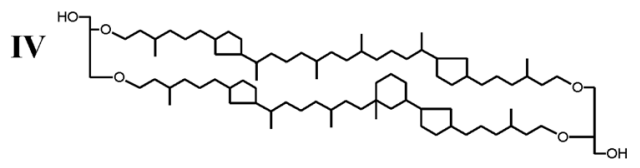

Figure 2. Chemical structures of the different branched glycerol dialkyl glycerol tetraethers (GDGTs) [from Weijers et al., 2007b].

A consequence of the strong and dynamic nature of sediment supply to the fan is that it is susceptible to reworking [e.g., Maslin et al., 1998]. Site 942 $\left(5^{\circ} 45^{\prime} \mathrm{N}, 49^{\circ} 6^{\prime} \mathrm{W}\right.$, water depth $\left.3346 \mathrm{~m}\right)$ was drilled as part of ODP Leg 155 and lies adjacent to the main Amazon Fan complex. It was chosen for this study because it is off the main fan and is thus less affected by the reworking which affects almost all of the other Leg 155 sites, but is still close enough to the main fan to receive terrigenous input and benefit from enhanced sedimentation rates during glacial periods (when sea levels were lower and the terrigenous sediment load within the river was transported directly to the fan) [Maslin et al., 2000]. The cores from this site have been examined in detail visually for any signs of reworking, including microturbidites [Maslin and Burns, 2000]. The youngest disturbed section found was at approximately 24 mbsf (meters below seafloor), which has been dated at about 40 kyr B.P. Possible temporal offsets between biomarkers and planktonic foraminifera identified in recent publications [Mollenhauer et al., 2005; Ohkouchi, 2002], have to be considered when interpreting biomarker data using an age model based on microfossil analysis. However, it is unlikely that any temporal offsets are large enough to compromise our conclusions reached by comparing glacial and interglacial sediments. The highresolution age model used is that of Ettwein [2005], which is based on 26 AMS radiocarbon dates from planktonic foraminifera (ages in calendar years).

\subsection{Biomarker Work-Up Procedure}

[8] For the ODP 942 sediment core samples, the total lipid extracts were obtained from $\sim 7$ to $10 \mathrm{~g}$ of freezedried, powdered sediment via $24 \mathrm{~h}$ Soxhlet extraction with a 2:1 (v/v) mixture of dichloromethane and methanol [Boot et al., 2006]. Extracts were treated with activated copper in order to remove elemental sulfur, and a standard mixture containing known amounts of androstane, hexadecan-2-ol and hexadecyl octadecanoate was added. Fractionation was carried out on a column $(4 \mathrm{~cm})$ packed with silica gel. A hydrocarbon fraction was collected by elution with $3 \mathrm{~mL}$ of hexane, and a polar fraction with $5 \mathrm{~mL}$ of dichloromethane followed by $3 \mathrm{~mL}$ of $1: 1$ dichloromethane:methanol. A final fraction containing the most polar compounds was collected using $3 \mathrm{~mL}$ of methanol. The middle fraction, contained the GDGTs.

[9] The 22 Amazon basin soil samples were extracted and analyzed using the methods of Weijers et al. [2007b]. Extraction was performed three times with an accelerated solvent extractor (ASE; DIONEX200) with a solvent mixture of dichloromethane (DCM)/methanol 9:1 (v/v) at a temperature of $100^{\circ} \mathrm{C}$ and a pressure of $7.6 \times 106 \mathrm{~Pa}$ for $5 \mathrm{~min}$. The obtained total extracts were rotary evaporated under near vacuum and separated over an activated $\mathrm{Al}_{2} \mathrm{O}_{3}$ column, using DCM and DCM/ methanol 1:1 (v/v), into an apolar and a polar fraction, respectively. The polar fraction contained the GDGTs. 


\subsection{HPLC/APCI-MS}

[10] The fractions containing the branched GDGTs were ultrasonically dissolved in a hexane/propanol 99:1 (v/v) mixture at a concentration of $2 \mathrm{mg} \mathrm{ml}^{-1}$ and filtered through an $0.45 \mu \mathrm{m}$ PTFE filter (ø $4 \mathrm{~mm}$ ) prior to analysis. The samples were analyzed by high-performance liquid chromatography/ atmospheric pressure chemical ionizationmass spectrometry (HPLC/APCI-MS) on an Agilent 1100 series/Hewlett-Packard 1100 MSD series machine equipped with automatic injector and HP Chemstation software according to Hopmans et al. [2000] with minor modifications. Separation was achieved in normal phase on an Alltech Prevail Cyano column $(150 \mathrm{~mm} \times 2.1 \mathrm{~mm} ; 3 \mu \mathrm{m})$. The flow rate of the hexane/propanol 99:1 (v/v) eluent was $0.2 \mathrm{ml} \mathrm{min}^{-1}$, isocratically for the first $5 \mathrm{~min}$, thereafter with a linear gradient to $1.8 \%$ propanol in $45 \mathrm{~min}$. Injection volume of the samples was $10 \mu \mathrm{l}$. In order to increase sensitivity and therefore reproducibility, ion scanning was performed in a single ion monitoring (SIM) mode [Schouten et al., 2007]. Quantification of the compounds was achieved by integrating the areas of the $[\mathrm{M}+\mathrm{H}]+$ (protonated molecular ion) peaks and comparing these with an external standard curve composed of known amounts of crenarchaeol (an isoprenoid GDGT). Further details of the integrations of peak responses for GDGT biomarkers for all m/z, GDGT indices, reconstructed temperatures and $\mathrm{pHs}$, and organic matter end-member calculations are given in the auxiliary material. ${ }^{1}$

\section{4. $\mathrm{MBT} / \mathrm{CBT}$ and BIT Indices}

[11] A detailed description of the definitions and characteristics of the Methylation index of Branched Tetraethers (MBT) and the Cyclization ratio of Branched Tetraethers (CBT) is provided by Weijers et al. [2007b]. The MBT index and CBT ratio were calculated as follows:

$$
\begin{gathered}
M B T=\frac{[I+I b+I c]}{[I+I b+I c]+[I I+I I b+I I c]+[I I I+I I I b+I I I c]} \\
C B T=-\operatorname{LOG}\left(\frac{([I b]+[I I b])}{([I]+[I I])}\right)
\end{gathered}
$$

The roman numerals correspond to those in Figure 2. The calibration formulae used to transfer the CBT ratio into $\mathrm{pH}$ and the $\mathrm{MBT}$ and $\mathrm{CBT}$ values into

\footnotetext{
${ }^{1}$ Auxiliary materials are available at $\mathrm{ftp} / / \mathrm{ftp}$.agu.org/apend/gc/ $2010 \mathrm{gc} 003308$.
}

annual MAT, on the basis of the global soil calibration of Weijers et al. [2007b], are:

$$
C B T=3.33-0.38 p H\left(R^{2}=0.70\right)
$$

$$
M B T=0.122+0.187 C B T+0.020 M A T\left(R^{2}=0.77\right)
$$

The analytical reproducibility based on pooled standard deviations of duplicate measurements of samples is $\leq 0.01$ units for the MBT index and \pm 0.01 units for the CBT ratio, or $\pm 0.02 \mathrm{pH}$ units and $\pm 0.2^{\circ} \mathrm{C}(1 \sigma)$ in the temperature estimates.

[12] The BIT index, a proxy for the relative fluvial input of terrestrial organic matter (TOM) in the marine environment [Hopmans et al., 2004] is derived from the following equation (roman numerals correspond to Figure 2):

$$
B I T=\frac{I+I I+I I I}{[I+I I+I I I]+[I V]}
$$

\section{Results and Discussion}

\subsection{Regional Amazon Basin MBT/CBT Calibration}

[13] Recent work has highlighted that in addition to the application of the global calibration, regional MBT/CBT calibrations could increase the accuracy of MBT/CBT-MAT reconstructions [Rueda et al., 2009; Sinninghe Damsté et al., 2008]. Thus, we produced a regional Amazon calibration, using samples collected from the World Soil Database collection of the International Soil Research and Information Centre (ISRIC) in Wageningen, Netherlands. The 22 soils cover a wide range of altitudes, $\mathrm{pH}$ and MAT (Table 1 and Figure 1). The 3-D regression plot for the new calibration is shown in Figure 3. The calibration formulae based on the Amazon basin calibration are:

$$
C B T=4.2313-0.5782 \times p H\left(R^{2}=0.75\right)
$$

$$
\begin{aligned}
M B T= & 0.1874+0.0829 \times C B T+0.0250 \\
& \times \operatorname{MAT}\left(R^{2}=0.91\right)
\end{aligned}
$$

The reconstructed MAT records from ODP 942 are illustrated in Figure 4. Recent work has highlighted that regional MBT calibrations could increase the accuracy of MBT/CBT-MAT reconstructions [Peterse et al., 2009b, 2009c; Rueda et al., 2009; Sinninghe Damsté et al., 2008]. Thus, we utilize the 
Table 1. Location of Soils in the Amazon Basin With MAT and pH Values Used for the Regional MBT/CBT Calibration

\begin{tabular}{|c|c|c|c|c|c|c|c|c|}
\hline Sample & $\begin{array}{l}\text { Depth } \\
(\mathrm{cm})\end{array}$ & Latitude & Longitude & $\begin{array}{l}\text { Altitude } \\
\text { (m) }\end{array}$ & $\begin{array}{l}\text { Nearest } \\
\text { Weather } \\
\text { Station }\end{array}$ & $\begin{array}{c}\text { Weather } \\
\text { Station MAT }\end{array}$ & $\begin{array}{c}\text { MBT/ } \\
\text { CBT-MAT }\end{array}$ & $\begin{array}{l}\text { Soil } \\
\text { pH }\end{array}$ \\
\hline \multirow[t]{2}{*}{ Peru 1} & $2-15$ & $3^{\circ} 49^{\prime} \mathrm{S}$ & $73^{\circ} 19^{\prime} \mathrm{W}$ & 150 & Iquitos & 26.2 & 25.1 & 4.5 \\
\hline & $15-27$ & & & & & 26.2 & 29.8 & 4.4 \\
\hline \multirow[t]{2}{*}{ Peru 4} & $0-14$ & $3^{\circ} 51^{\prime} \mathrm{S}$ & $73^{\circ} 18^{\prime} \mathrm{W}$ & 130 & & 26.2 & 24.9 & 4.0 \\
\hline & $14-39$ & & & & & 26.2 & 26.7 & 5.2 \\
\hline \multirow[t]{2}{*}{ Peru 6} & $0-8$ & $5^{\circ} 46^{\prime} \mathrm{S}$ & $76^{\circ} 05^{\prime} \mathrm{W}$ & 180 & Yurimaguas & 26.9 & 25.1 & 4.1 \\
\hline & $8-25$ & & & & & 26.9 & 25.8 & 4.6 \\
\hline \multirow[t]{2}{*}{ Peru 10} & $0-10$ & $12^{\circ} 41^{\prime} \mathrm{S}$ & $69^{\circ} 08^{\prime} \mathrm{W}$ & 260 & Pt Maldonado & 25.5 & 23.6 & 4.4 \\
\hline & $10-25$ & & & & & 25.5 & 26.2 & 4.5 \\
\hline \multirow[t]{2}{*}{ Peru 12} & $0-5$ & $4^{\circ} 04^{\prime} \mathrm{S}$ & $73^{\circ} 27^{\prime} \mathrm{W}$ & 130 & Iquitos & 26.2 & 32.2 & 4.9 \\
\hline & $5-22$ & & & & & 26.2 & 27.9 & 4.3 \\
\hline \multirow[t]{2}{*}{ Peru 13} & $0-15$ & $3^{\circ} 55^{\prime} \mathrm{S}$ & $73^{\circ} 22^{\prime} \mathrm{W}$ & 130 & Iquitos & 26.2 & 29.1 & \\
\hline & $15-55$ & & & & & 26.2 & 32.0 & \\
\hline \multirow[t]{2}{*}{ Peru 14} & $0-8$ & $3^{\circ} 55^{\prime} \mathrm{S}$ & $73^{\circ} 22^{\prime} \mathrm{W}$ & 130 & Iquitos & 26.2 & 27.9 & \\
\hline & $8-25$ & & & & & 26.2 & 26.3 & \\
\hline Ecuador 3 & $0-26$ & $0^{\circ} 32^{\prime} \mathrm{S}$ & $78^{\circ} 38^{\prime} \mathrm{W}$ & 4000 & Quito & $8.4^{\mathrm{a}}$ & 4.2 & 5.6 \\
\hline Ecuador 6 & $0-18$ & $0^{\circ} 31^{\prime} \mathrm{S}$ & $76^{\circ} 56^{\prime} \mathrm{W}$ & 250 & Iquitos & 26.2 & 28.7 & 4.9 \\
\hline \multirow{2}{*}{ Ecuador 7} & $0-8$ & $0^{\circ} 19^{\prime} \mathrm{S}$ & $76^{\circ} 50^{\prime} \mathrm{W}$ & 260 & Iquitos & 26.2 & 28.1 & 4.6 \\
\hline & $8-38$ & & & & & 26.2 & 25.0 & 4.8 \\
\hline Ecuador 19 & $0-50$ & $2^{\circ} 07^{\prime} \mathrm{S}$ & $78^{\circ} 43^{\prime} \mathrm{W}$ & 2780 & Pastaza & $12.7^{\mathrm{a}}$ & 12.7 & 6.6 \\
\hline \multirow[t]{2}{*}{ Brazil 12} & $0-5$ & $2^{\circ} 36^{\prime} \mathrm{S}$ & $54^{\circ} 57^{\prime} \mathrm{W}$ & 60 & Belterra & 24.9 & 32.7 & 6.2 \\
\hline & $5-38$ & & & & & 24.9 & 34.1 & 6.6 \\
\hline \multirow[t]{2}{*}{ Brazil 13} & $0-7$ & $2^{\circ} 54^{\prime} \mathrm{S}$ & $54^{\circ} 56^{\prime} \mathrm{W}$ & 75 & Belterra & 24.9 & 25.3 & 3.9 \\
\hline & $7-25$ & & & & & 24.9 & 28.2 & 4.5 \\
\hline \multirow[t]{2}{*}{ Brazil 14} & $0-9$ & $15^{\circ} 36^{\prime} \mathrm{S}$ & $47^{\circ} 42^{\prime} \mathrm{W}$ & 1010 & Brasilia & 21.2 & 17.9 & 4.0 \\
\hline & $9-20$ & & & & & 21.2 & 23.5 & 4.3 \\
\hline \multirow[t]{2}{*}{ Brazil 28} & $0-10$ & $12^{\circ} 00^{\prime} \mathrm{S}$ & $50^{\circ} 00^{\prime} \mathrm{W}$ & 200 & Peixe & 25.6 & 30.6 & 5.9 \\
\hline & $10-22$ & & & & & 25.6 & 28.9 & 5.6 \\
\hline Colombia 7 & $0-20$ & $0^{\circ} 28^{\prime} \mathrm{S}$ & $72^{\circ} 14^{\prime} \mathrm{W}$ & 200 & Iquitos & 26.2 & 24.5 & 4.2 \\
\hline Colombia 8 & $8-21$ & $0^{\circ} 24^{\prime} \mathrm{N}$ & $72^{\circ} 09^{\prime} \mathrm{W}$ & 230 & Iquitos & 26.2 & 23.6 & 4.2 \\
\hline \multirow[t]{2}{*}{ Colombia 9} & $0-10$ & $0^{\circ} 28^{\prime} \mathrm{S}$ & $72^{\circ} 13^{\prime} \mathrm{W}$ & 290 & Iquitos & 26.2 & 23.7 & 3.8 \\
\hline & $10-20$ & & & & & 26.2 & 24.5 & 4.4 \\
\hline \multirow[t]{3}{*}{ Colombia 10} & $0-5$ & $0^{\circ} 27^{\prime} \mathrm{S}$ & $72^{\circ} 13^{\prime} \mathrm{W}$ & 340 & Iquitos & 26.2 & 25.0 & 4.0 \\
\hline & $5-13$ & & & & & 26.2 & 26.2 & 4.6 \\
\hline & $13-21$ & & & & & 26.2 & 27.0 & 4.7 \\
\hline Colombia 11 & $0-30$ & $1^{\circ} 07^{\prime} \mathrm{N}$ & $77^{\circ} 22^{\prime} \mathrm{W}$ & 3100 & Ipiales & 10.8 & 9.1 & 4.6 \\
\hline Colombia 12 & $0-30$ & $1^{\circ} 20^{\prime} \mathrm{N}$ & $77^{\circ} 20^{\prime} \mathrm{W}$ & 2350 & & $13.8^{\mathrm{a}}$ & 22.0 & 4.8 \\
\hline Colombia 14 & $0-30$ & $1^{\circ} 10^{\prime} \mathrm{N}$ & $77^{\circ} 22^{\prime} \mathrm{W}$ & 3810 & & $6.6^{\mathrm{a}}$ & 5.6 & 5.5 \\
\hline
\end{tabular}

${ }^{\text {a}}$ Adjusted using lapse rate of $0.5^{\circ} \mathrm{C} / 100 \mathrm{~m}$ between site and weather station.

new regional Amazon calibration (green line) in addition to the Weijers et al. [2007b] global calibration (brown line). The two trends are similar, due to the general similarity of the calibration slopes, however the Amazon calibration gives MATs on average $2^{\circ} \mathrm{C}$ cooler $\left(1\right.$ s.d. $\left.=1{ }^{\circ} \mathrm{C}\right)$. Our regional Amazon calibration confirms the general applicability of the global calibration set, but also suggests regional data sets can refine results. Henceforth we discuss MBT/ CBT-MAT data primarily based on the Amazon calibration. Prior to $11.3 \mathrm{kyr}$ B.P. the temperature trends show minima at $32.5,27,16.5$ and $11.5 \mathrm{kyr}$ B.P. and maxima at $35.5,32,18$, and $11.3 \mathrm{kyr}$ B.P. The sharp warming at $11.3 \mathrm{kyr}$ B.P. is determined by only one data point. This is followed by an apparent cooling throughout the early Holocene to $\sim 10^{\circ} \mathrm{C}$ at $6.3 \mathrm{kyr}$ B.P. and a subsequent warming trend to the top of the core (Figure 4).

\subsection{Glacial-Holocene Changes in Organic Carbon Provenance}

[14] Insights into the changes in terrestrial sediment supply to ODP 942 can be gained from the BIT index [Hopmans et al., 2004]. The BIT index shows a large decrease between 13 and $10 \mathrm{kyr}$ B.P. (Figure 4c) coeval with the latter main phase of deglacial global eustatic sea level rise [McGuire et al., 1997]. This transition represents a reduction in the relative proportion of terrestrial material reaching site 942 as, during the marine transgression, the mouth of the Amazon River becomes more distal from ODP 942 and increasing propor- 


\section{Soils Amazon Basin}

$$
\begin{aligned}
& \mathrm{MBT}=0.1874+0.0829^{*} \mathrm{CBT}+0.0250^{\star} \mathrm{MAT} \\
& \mathrm{R}^{2}=0.91
\end{aligned}
$$

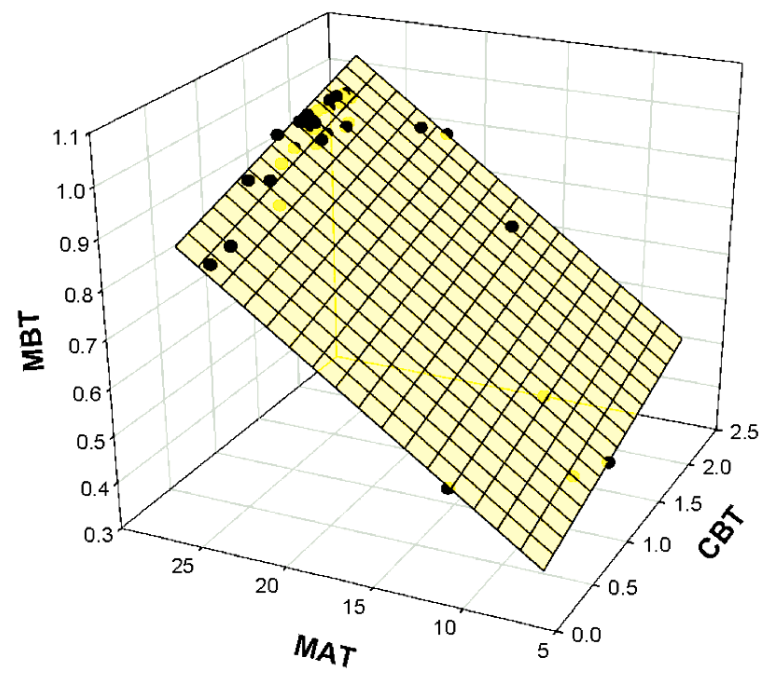

Figure 3. Plot showing relationship between MAT, MBT index, and CBT ratio measured in Amazon basin soils.

tions of terrestrial material are deposited on the flooded continental shelf. However, the BIT index recovers somewhat and remains relatively high during the Holocene, suggesting continued, significant inputs of terrestrial material to ODP 942 (Figure 4c).

[15] A recent study by Peterse et al. [2009a] indicates that branched GDGTs may also be produced in situ in marine sediments in small quantities and that MBT/CBT-derived MAT values may be biased by marine derived branched GDGTs in settings with low soil organic matter inputs. Peterse et al. [2009a] found this for marine sediments with low BIT index values of 0.01 to 0.02 . It is unlikely that marine branched GDGTs have a significant imprint on our records from ODP 942. The BIT index is high during the glacial (BIT $=\sim 0.5$ to 0.8 ; Figure $4 \mathrm{c}$ ) and even the lowest value $(\mathrm{BIT}=0.1)$ reached during the marine transgression shows an order of magnitude more terrestrial input than the settings $(\mathrm{BIT}=0.01$ to 0.02) where Peterse et al. [2009a] found significant bias. Furthermore, Rueda et al. [2009] recently reported realistic air temperature reconstructions using the MBT/CBT paleothermometer for marine sediments from the Skagerak with low BIT values $\sim 0.07$.
[16] The MBT/CBT proxy is interpreted as a sediment flux weighted average proxy for MAT. Previous work suggests this proxy is capable of integrating average MAT changes for large regional areas. In the reconstruction of glacial through Holocene MAT changes from the Congo basin, Weijers et al. [2007a] produced a convincing glacial-Holocene MAT reconstruction that compares well with previous tropical temperature reconstructions and even far-field records from ice cores. Seemingly the primary MAT record from the Congo basin was not influenced by any changes, over time, in the source areas of terrestrial organic material.

[17] However, it is also recognized that the integrated MAT signal will be weighted toward the catchment areas that supply the greatest flux of terrestrial sediments and associated organic material. Furthermore, the flux of transported branched GDGTs will not be proportionally equivalent to sediment supplied from different catchment areas, as the organic carbon (and branched GDGT) content of transported sediments will vary spatially and temporally. As described above (and shown in Figure 4), our Amazon MAT estimates vary between 19.6 and $23.4^{\circ} \mathrm{C}$ up to $11.3 \mathrm{kyr}$ B.P., but this is followed by an apparent, and unexpected, drop to $\sim 10^{\circ} \mathrm{C}$ by the mid-Holocene (6.5 kyr B.P.). Temperatures then increase over the course of the Holocene to $17.4^{\circ} \mathrm{C}$ in the most recent sample. We suggest that the ODP $942 \mathrm{MBT} / \mathrm{CBT}$ record after 11.3 kyr B.P. primarily reflects catchment dynamics, i.e., changes in the supply of organic matter to the Amazon fan.

[18] Studies of the mineralogy of the Amazon River suggests the modern sediment load has two distinct source areas: the Andes/western Amazonia and central/eastern Amazonia [Rimington, 1999]. Currently the Andean region accounts for $12 \%$ of the catchment area but supplies an estimated $\sim 82 \%$ to $95 \%$ of the suspended sediment, [Gibbs, 1967; Meade, 1985; Meade et al., 1985] and $~ 80 \%$ of the dissolved ions to the river system [Stallard and Edmond, 1983]. Therefore, it is reasonable that the relatively cold Andean region (i.e., with an MAT of $<0$ to $10^{\circ} \mathrm{C}$, see Figure 1a) should have a major impact on the MBT/CBT-MAT signal recorded in the Amazon fan sediments of ODP 942 (Figure 1a). It has been suggested that during the Last Glacial Maximum, advancing ice would have substantially reduced sediment supply from the Andean region [Rimington, 1999]. Therefore, the glacial ODP Site 942 MBT/CBT-MAT signal likely has a primary provenance in the central/ eastern Amazon region, as the glacial ice restricted 

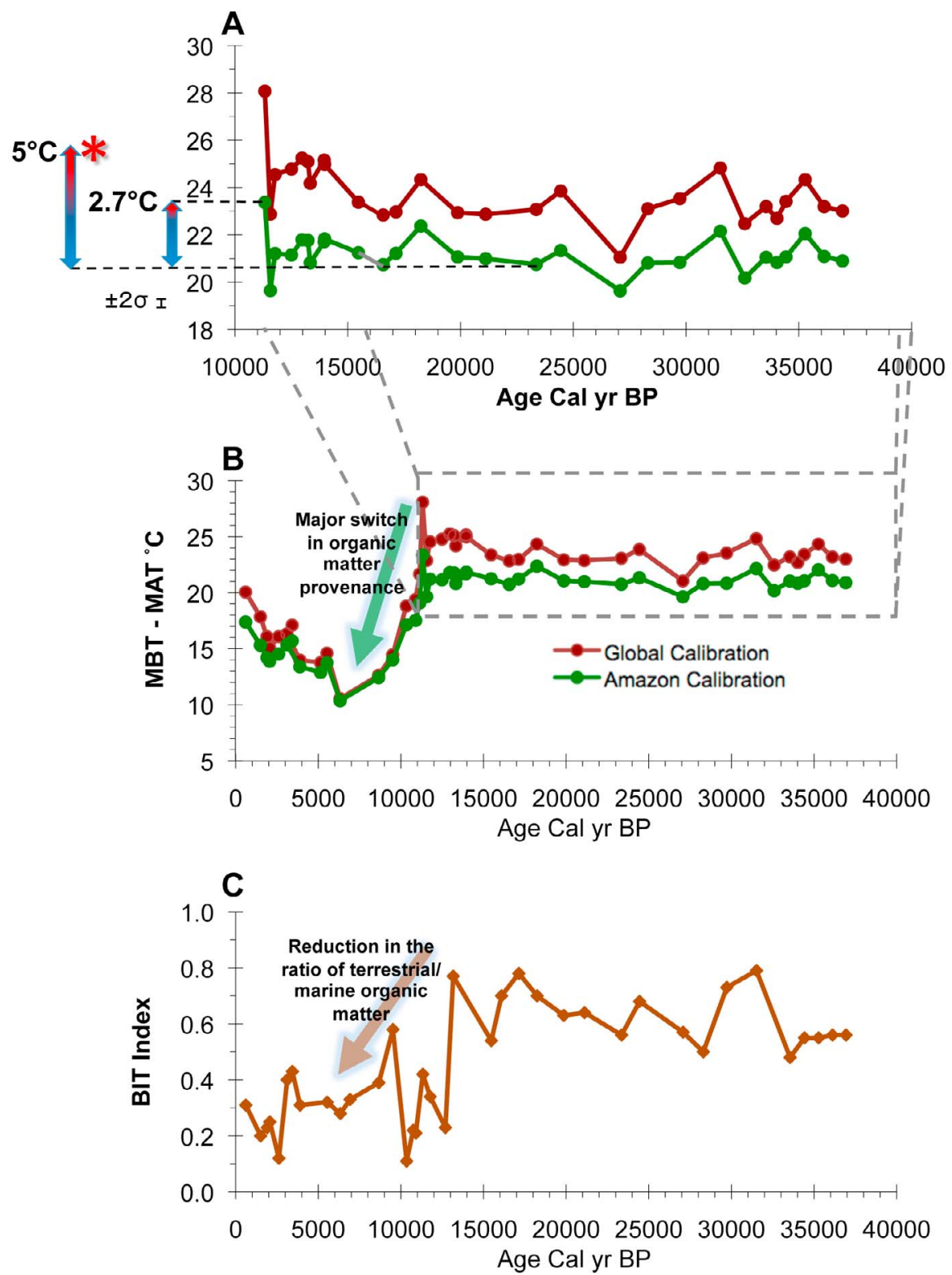

Figure 4. Age profiles measured in ODP core 942 for (a) $\mathrm{MAT}{ }^{\circ} \mathrm{C}$ (expanded $y$ axis) and (b) $\mathrm{MAT}{ }^{\circ} \mathrm{C}$ (derived from the MBT and CBT indices). The asterisk $\left(25.8^{\circ} \mathrm{C}\right)$ indicates the modern mean air temperature of the central/eastern Amazon $(<1000 \mathrm{~m}$ altitude) (World Climate Information (WKI) weather station data, see EA) and is compared with the reconstructed MBT-derived temperature for the LGM $\left(\sim 5^{\circ} \mathrm{C}\right.$ cooler). The green arrow in Figure $4 \mathrm{~b}$ indicates a major switching of sediment provenance during early Holocene as sediment supply from the Andes and foothills increases relative to the central/eastern Amazon source. (c) Plot of the branched versus isoprenoid tetraether (BIT) index in ODP 942, a proxy for the relative fluvial input of terrestrial organic matter in the marine environment.

sediment inputs from the Andes/western Amazonia and reduced precipitation in the basin [Maslin and Burns, 2000]. During the deglaciation, ablation of Andean ice was initiated, however, it seems a key threshold in the basin sediment regime was not passed until later at $\sim 11.3 \mathrm{kyr}$ B.P., perhaps also reflecting a major reorganization of the drainage network. At this time, as Andean ice continued to retreat and rainfall increased sharply in the Amazon basin [Maslin and Burns, 2000], sediment supply from the Andes and foothills could have increased rapidly relative to the central/eastern Amazon source. This event follows shortly after the "Amazon discharge event" recorded in the site $942 \mathrm{~N}$. dutertrei $\delta^{18} \mathrm{O}$ record at $11.8 \mathrm{kyr}$ B.P. [Maslin and Burns, 2000] and a major warming of the Andes ice sheet 


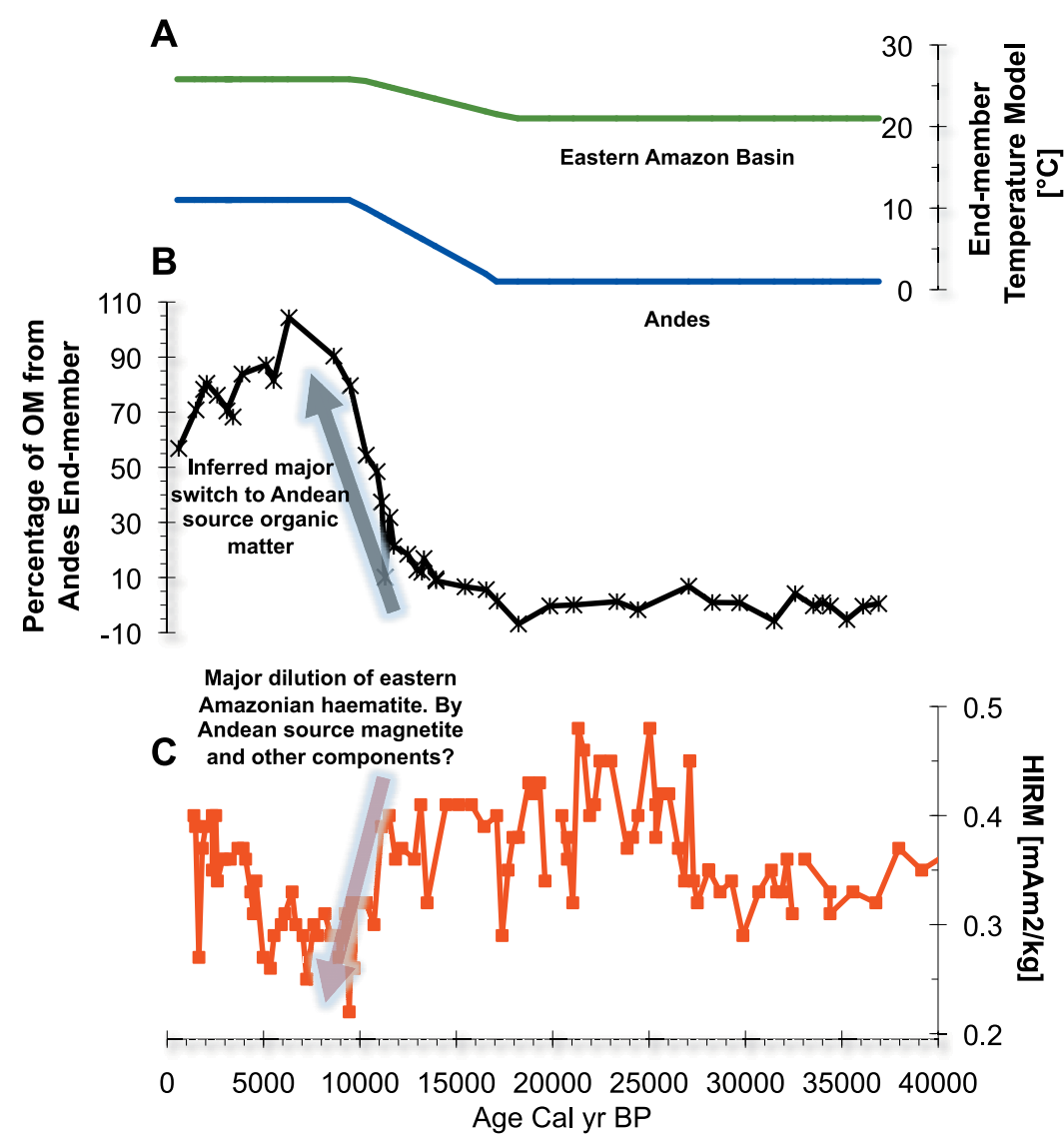

Figure 5. (a) Model of evolving temperatures for the eastern Amazonian and Andes mixing model end-members. The modern end-member values for the mixing equation are averages of World Climate Information (WKI) weather station data, whereas the glacial end-member values derive from proxy records. (b) Estimated percentage input of branched GDGTs (and by extension organic matter) to ODP 942 from the Andes source region. Estimates were made using the two-component mixing equation. (c) Plot of HIRM ("hard" isothermal remnant magnetization) measured in ODP 942 (replotted from Durham [1997]).

at the termination of the Younger Dryas [Thompson et al., 1995].

[19] We suggest the relative increase in Andean sediment flux incorporated organic material and associated soil bacterial branched GDGTs from the Montane and Páramo vegetation belts (Figure 1b) which carried a relatively cold temperature signal (relative to central/eastern Amazonia Lowland rain forest vegetation belt) from $11.3 \mathrm{kyr}$ B.P. onward. Relative changes in the fractional supply of branched GDGTs (and by extension organic matter and sediments) from the cold Andean region can be explored by using a two-component mixing equation:

$$
\% G D G T_{\text {Andes }}=\frac{M A T_{\text {Sample }}-M A T_{E A}}{M A T_{\text {Andes }}-M A T_{E A}} \times 100
$$

where $\mathrm{MAT}_{\text {Sample }}$ is the MBT/CBT derived MAT value of a sample, and $\mathrm{MAT}_{\mathrm{EA}}$ and $\mathrm{MAT}_{\text {Andes }}$ are the end-members: the changing mean annual temperatures of the central/eastern Amazon and Andean source regions, respectively. We use a simple model for the end-member temperatures (Figure 5a). The modern end-member values for the mixing equation are averages of World Climate Information (WKI) weather station data, whereas the glacial end-member values derive from proxy records. For the glacial and deglacial period of the record from 37 to $18 \mathrm{kyr}$ B.P., the central/eastern Amazon $\left(<1000 \mathrm{~m}\right.$ altitude) $\mathrm{MAT}_{\mathrm{EA}}=21^{\circ} \mathrm{C}$ (based on noble gases [Stute et al., 1995] and pollen [Bush and Silman, 2004; Bush et al., 2001]); for the Andean region $\mathrm{MAT}_{\text {Andes }}=1{ }^{\circ} \mathrm{C}$ (based on Peruvian ice core based estimates that glacial stage conditions in the high tropics were $\sim 10^{\circ} \mathrm{C}$ cooler than today [Thompson et al., 1995]). Between $18 \mathrm{kyr}$ and $10 \mathrm{kyr}$ B.P. the end-member MAT values are increased in a linear fashion to present-day values (central/eastern Amazon $\left(<1000 \mathrm{~m}\right.$ altitude) $\mathrm{MAT}_{\mathrm{EA}}=25.8^{\circ} \mathrm{C}$; for 
the Andean region $\mathrm{MAT}_{\text {Andes }}=11^{\circ} \mathrm{C}$ ), which are obtained by $10 \mathrm{kyr}$ B.P. and held up to the presentday situation.

[20] This calculation results sometimes in estimates of Andean organic matter supply from $<0 \%$ to $>100 \%$ (Figure 5b). These estimates contain considerable uncertainties due to factors including shifting foci of erosional activity (i.e., within the two broad regions it is unknown which localities contributed most organic material, or how this changed over time). We acknowledge the large unknown error margins and emphasize this as a data exploration exercise. Nonetheless, the data show variable but low Andean inputs up to $16.5 \mathrm{kyr}$ B.P. $(\sim<\%-7 \%)$, steadily increasing Andean inputs during the deglacial, from 16.5 to $11.5 \mathrm{kyr}$ B.P. ( $\sim 5 \%$ to $50 \%$ ) with a sharp increase at $\sim 11.3 \mathrm{kyr}$ B.P., reaching a maximum at $\sim 6 \mathrm{kyr}$ B.P. $(\sim 100 \%)$, with a stepped decease through the Late Holocene to $60 \%$ in the most shallow sediment dated to $\sim 600 \mathrm{kyr}$ B.P.

[21] A major change in sedimentary regime at $\sim 11.5 \mathrm{kyr}$ B.P. is further supported by a change in the HIRM parameter ("hard" isothermal remnant magnetization) (Figure 5c, replotted from Durham [1997]). HIRM is a measure of the concentration of high-coercivity antiferromagnetic minerals, such as haematite and goethite [Thompson and Oldfield, 1986] and is often assumed to represent haematite concentration [Hall, 1990]. Haematite and goethite are major mineral components of the ferralitic soils (and a factor in the associated red-yellow coloration) which extend widely in the tropical lowland regions of the Amazon [Fritsch et al., 2005]. In such soils these minerals are finely divided and closely associated into aggregates in loose soil horizons, and thus amenable to erosion and riverine transport [Fritsch et al., 2005]. Therefore, the HIRM parameter in ODP 942 may be greatly influenced by the supply of haematite and goethite associated with eastern Amazonian soil material. At 11.3 kyr B.P., coeval with the inferred switch to cold Andean source branched GDGTs, is a major fall in the HIRM parameter (Figure 5c). We suggest this represents a major dilution of the eastern Amazonian (ferralitic soil) haematite and goethite by other components, including low-coercivity ferrimagnetic minerals such as magnetite in andesites originating from the Andes. The inverse correlation between the organic branched GDGT temperature reconstructions and inorganic HIRM from $11.3 \mathrm{kyr}$ B.P. is remarkable. Both suggest a major switch from eastern Amazonian to Andean sources of sediment at $11.3 \mathrm{kyr}$ B.P., which reached a peak during the mid-Holocene thermal maximum at $\sim 6.3 \mathrm{kyr}$ B.P.

\subsection{Central/Eastern Amazon Glacial Temperatures}

[22] Figure 4a (with an expanded $y$ axis) shows changes in estimated temperature prior to $11.3 \mathrm{kyr}$ B.P. During this period we assume sediments accumulating at ODP 942 have a primary provenance in the central/eastern Amazon region. Using the regional Amazon calibration, our record shows that temperatures varied during the glacial (37-11.5 kyr B.P.) between 19.6 to $22.2^{\circ} \mathrm{C}$ with a mean of $21.1^{\circ} \mathrm{C}$. The modern mean annual temperature of the central/eastern Amazon ( $<1000 \mathrm{~m}$ altitude) is $25.8^{\circ} \mathrm{C}$ (WKI weather station data). Thus, we estimate a glacial cooling of $\sim 5^{\circ} \mathrm{C}$. This is in line with earlier temperature reconstructions for the Amazon basin based on groundwater noble gases [Stute et al., 1995] and pollen assemblages, both suggesting lowland Brazil air temperatures were $5^{\circ} \mathrm{C}$ cooler at the LGM than today [Bush and Silman, 2004; Bush et al., 2001]. For the Central African tropics, using the same MBT/CBT based temperature reconstruction, Weijers et al. [2007a] estimate an LGM cooling of $\sim 4$ to $5^{\circ} \mathrm{C}$. This appears to further validate the paleotemperature application of the MBT/CBT-MAT proxy at this site and suggests that prior to $11.6 \mathrm{kyr}$ B.P. the ODP Site 942 core does record a temperature signal with provenance in the central/eastern Amazon basin. Moreover, it confirms that the previous geographically more restricted lacustrine pollen [e.g., Bush et al., 2001; Ledru et al., 2001; van der Hammen and Hooghiemstra, 2000] and noble gas [Stute et al., 1995] based temperature records are representative of the central/eastern Amazon lowland.

\section{Conclusions}

[23] The MBT/CBT-derived MAT data from core ODP 942 confirms the applicability of the branched GDGT proxies for reconstructing basin-scale changes in temperature. We estimate a regional lowland Amazon Last Glacial Maximum temperature that is $\sim 5^{\circ} \mathrm{C}$ cooler than the present day, in line with previous lowland Amazon and African tropical estimates. However, crucially, our record also demonstrates how on a catchment basin scale the MBT/CBT-MAT proxy integrates changes in soil temperature and sedimentary regime. Thus, changes in basin dynamics and sediment provenance must be taken into account when interpreting MBT/CBT-derived MAT records. In fact this work highlights the potential application of GDGTs for 
investigating catchment-scale changes in sedimentary regime. Such changes may be associated with orbital-scale climatic changes on time scales of $10^{5}$ years or, feasibly, orogeny and changes in paleoaltitude on time scales of $>10^{7}$ years. Thus this paper highlights both the continuing potential and required constraints for the recently developed $\mathrm{MBT} / \mathrm{CBT}$ continental paleothermometer.

\section{Acknowledgments}

[24] The authors thank Walter Hale, ODP Core Repository, Bremen for samples; Jort Ossebaar and Marianne Baas for technical support at NIOZ; and the Department of Geographical and Earth Science, University of Glasgow, drawing office for drafting Figure 1. NERC grant NE/C508934/1 to R.D.P. and M.M. provided financial support. J.B., M.M., and R.D.P. gratefully acknowledge funding support for a NERC-IODP Post-Doctoral Research Associate salary. J.B. thanks staff and colleagues at the NERC Life Sciences Mass Spectrometry Facility (Bristol node) and OGU for technical help and discussions and two anonymous reviewers, whose constructive and generous reviews greatly improved the manuscript.

\section{References}

Boot, C. S., V. J. Ettwein, M. A. Maslin, C. E. Weyhenmeyer, and R. D. Pancost (2006), A 35,000 year record of terrigenous and marine lipids in Amazon Fan sediments, Org. Geochem., 37, 208-219, doi:10.1016/j.orggeochem.2005.09.002.

Bush, M. B., and M. R. Silman (2004), Observations on Late Pleistocene cooling and precipitation in the lowland Neotropics, J. Quat. Sci., 19, 677-684, doi:10.1002/jqs.883.

Bush, M. B., et al. (2001), Paleotemperature estimates for the lowland Americas between $30^{\circ} \mathrm{S}$ and $30^{\circ} \mathrm{N}$ at the Last Glacial Maximum, in Interhemispheric Climate Linkages, edited by V. Markgraf, pp. 293-306, doi:10.1016/B978-012472670-3/ 50020-3, Academic, San Diego, Calif.

Cowling, S. A., M. A. Maslin, and M. T. Sykes (2001), Paleovegetation simulations of lowland Amazonia and implications for neotropical allopatry and speciation, Quat. Res., 55, 140-149, doi:10.1006/qres.2000.2197.

Durham, E. (1997), Reconstructing the climatic history of the western coast of Africa over the past 1.5 million years: A comparison of proxy records from the Congo Basin and the Walvis Ridge, Ph.D. thesis, Univ. Coll. London, London.

Ettwein, V. (2005), Reconstruction of the effective moisture history of the Amazon basin for the last $40 \mathrm{kyr}$ from ODP Site 942 on the Amazon fan, Ph.D. thesis, Dep. of Geogr., Univ. Coll. London, London.

Flood, R. D., and D. J. W. Piper (1997), Amazon fan sedimentation: The relationship to equatorial climate change, continental denudation, and sea-level fluctuations, Proc. Ocean Drill. Program Sci. Results, 155, 653-675, doi:10.2973/ odp.proc.sr.155.246.1997.

Flood, R. D., D. J. W. Piper, and Shipboard Scientific Party (1995), Introduction, Proc. Ocean Drill. Program Initial Rep., 155, 5-16.
Franzinelli, E., and P. Potter (1983), Petrology, chemistry and texture of Amazon River sands, Amazon River system, J. Geol., 91, 23-39, doi, 10.1086/628742.

Fritsch, E., G. Morin, A. Bedidi, D. Bonnin, E. Balan, S. Caquineau, and G. Calas (2005), Transformation of haematite and Al-poor goethite to Al-rich goethite and associated yellowing in a ferralitic clay soil profile of the middle Amazon basin (Manaus, Brazil), Eur. J. Soil Sci., 56, 575588, doi:10.1111/j.1365-2389.2005.00693.x.

Gibbs, R. J. (1967), The geochemistry of the Amazon River system: Part 1 . The factors that control the salinity and the composition and concentration of the suspended solids, Geol. Soc. Am. Bull., 78, 1203-1232, doi:10.1130/00167606(1967)78[1203:TGOTAR]2.0.CO;2.

Grimm, A. M., and P. L. Silvia Dias (1995), Analysis of tropical-extratropical interactions with influence of a barotrophic model, J. Atmos. Sci., 52, 3538-3555, doi:10.1175/ 1520-0469(1995)052<3538:AOTIWI>2.0.CO;2.

Haberle, S. G., and M. A. Maslin (1999), Late Quaternary vegetation and climate change in the Amazon basin based on a 50,000 year pollen record from the Amazon fan, ODP site 932, Quat.Res., 51, 27-38, doi:10.1006/qres.1998.2020.

Haffer, J. (1969), Speciation in Amazonian forest birds, Science, 165, 131-137, doi:10.1126/science.165.3889.131.

Haffer, J., and G. T. Prance (2001), Climatic forcing of evolution in Amazonia during the Cenozoic: On the refuge theory of biotic differentiation, Amazoniana, 16, 579-605.

Hall, F. R. (1990), The rock-magnetic signature of highlatitude northern hemispheric deep-sea sediments and their relationships to Quaternary glacial cycling, Ph.D. thesis, Univ. of R. I., Kingston.

Hedges, J. I., R. G. Keil, and R. Benner (1997), What happens to terrestrial organic matter in the ocean?, Org. Geochem., 27, 195-212, doi:10.1016/S0146-6380(97)00066-1.

Herfort, L., S. Schouten, J. P. Boon, M. Woltering, M. Baas, J. W. H. Weiers, and J. S. Sinninghe Damsté (2006), Characterization of transport and deposition of terrestrial organic matter in the southern North Sea using the BIT index, Limnol. Oceanogr., 51, 2196-2205, doi:10.4319/ lo.2006.51.5.2196.

Hinrichs, K.-U., and J. Rullkötter (1997), Terrigenous and marine lipids in Amazon Fan sediments: Implications for sedimentological reconstructions, Proc. Ocean Drill. Program Sci. Results, 155, 539-553.

Hooghiemstra, H. (1984), Vegetation and Climatic History of the High Plain of Bogota, Colombia: A Continuous Record of the Last 3.5 Million Years, Cramer, Berlin.

Hopmans, E. C., S. Schouten, R. D. Pancost, M. T. J. Van der Meer, and J. S. Sinninghe Damsté (2000), Analysis of intact tetraether lipids in archaeal cell material and sediments by high performance liquid chromatography/atmospheric pressure chemical ionization mass spectrometry, Rapid Commun. Mass Spectrom., 14, 585-589, doi:10.1002/(SICI)1097-0231 (20000415)14:7<585::AID-RCM913>3.0.CO;2-N.

Hopmans, E. C., J. W. H. Weijers, E. Schefuss, L. Herfort, J. S. Sinninghe Damsté, and S. Schouten (2004), A novel proxy for terrestrial organic matter in sediments based on branched and isoprenoid tetraether lipids, Earth Planet. Sci. Lett., 224, 107-116, doi:10.1016/j.epsl.2004.05.012.

Kim, J. H., R. Buscail, B. Bzarzycka, P. Kerherve, F. Peterse, S. Schouten, W. Ludwig, and J. S. Sinninghe Damsté (2008), Tracking soil organic matter export across the continentocean interface: A case study of the NW Mediterranean using the BIT index, Geochim. Cosmochim. Acta, 72, A472. 
Kim, J.-H., B. Zarzycka, R. Buscail, F. Peterse, J. Bonnin, W. Ludwig, S. Schouten, and J. S. Sinninghe Damsté (2010), Contribution of river-borne soil organic carbon to the Gulf of Lions (NW Mediterranean), Limnol. Oceanogr., $55,507-518$.

Ledru, M.-P., R. C. Cordeiro, J. M. L. Dominguez, L. Martin, P. Mourguiart, A. Sifeddine, and B. Turcq (2001), Lateglacial cooling in Amazonia inferred from pollen at Lagoa do Caçó, northern Brazil, Quat. Res., 55, 47-56, doi:10.1006/ qres.2000.2187.

Legates, D. R., and C. J. Willmott (1990), Mean seasonal and spatial variability in global surface air temperature, Theor. Appl. Climatol., 41, 11-21, doi:10.1007/BF00866198.

Malhi, Y., P. Meir, and S. Brown (2002), Forests, carbon and global climate, Philos. Trans. R. Soc. London A, 360, 1567-1591, doi:10.1098/rsta.2002.1020.

Marengo, J., and C. A. Nobre (2001), The hydroclimatological framework in Amazonia, in Biogeochemistry of Amazonia, edited by J. Richey, M. McClaine, and R. Victoria, pp. 17-42, Oxford Univ. Press, Oxford, U. K.

Maslin, M. A., and S. J. Burns (2000), Reconstruction of the Amazon basin effective moisture availability over the past 14,000 years, Science, 290, 2285-2287.

Maslin, M., N. Mikkelsen, C. Vilela, and B. Haq (1998), Sealevel- and gas-hydrate-controlled catastrophic sediment failures of the Amazon fan, Geology, 26, 1107-1110, doi:10.1130/0091-7613(1998)026<1107:SLAGHC >2.3.CO, 2.

Maslin, M. A., et al. (2000), Palaeoreconstruction of the Amazon River freshwater and sediment discharge using sediments recovered at Site 942 on the Amazon Fan, J. Quat. Sci., 15, 419-434, doi:10.1002/1099-1417(200005)15:4<419:: AID-JQS541>3.0.CO;2-L.

Maslin, M., Y. Malhi, O. Phillips, and S. Cowling (2005), New views on an old forest: Assessing the longevity, resilience and future of the Amazon rainforest, Trans. Inst. Br. Geogr., 30, 477-499, doi:10.1111/j.1475-5661.2005.00181.x.

McGuire, W. J., R. J. Howarth, C. R. Firth, A. R. Solow, A. D. Pullen, S. J. Saunders, I. S. Stewart, and C. Vita-Finzi (1997), Correlation between rate of sea level change and frequency of explosive volcanism in the Mediterranean, Nature, 389, 473-476, doi:10.1038/38998.

Meade, R. H. (1985), Suspended sediment in the Amazon River and its tributaries in Brazil during 1982-1984, U.S. Geol. Surv. Open File Rep., 85-492, 39 pp.

Meade, R. H., T. Dunne, J. E. Richey, U. M. Santos, and E. Salati (1985), Storage and remobilization of suspended sediment in the lower Amazon River of Brazil, Science, 228, 488-490, doi:10.1126/science.228.4698.488.

Mollenhauer, G., M. Kienast, F. Lamy, H. Meggers, R. R. Schneider, J. M. Hayes, and T. I. Eglinton (2005), An evaluation of ${ }^{14} \mathrm{C}$ age relationships between co-occurring foraminifera, alkenones, and total organic carbon in continental margin sediments, Paleoceanography, 20, PA1016, doi:10.1029/2004PA001103.

Morley, R. J. (2000), Origin and Evolution of Tropical Rain Forests, John Wiley, Chichester, U. K.

Ohkouchi, N. (2002), Spatial and temporal offsets between proxy records in a sediment drift, Science, 298, 12241227, doi:10.1126/science.1075287.

Pancost, R. D., and C. S. Boot (2004), The palaeoclimatic utility of terrestrial biomarkers in marine sediments, Mar. Chem., 92, 239-261, doi:10.1016/j.marchem.2004.06.029.

Peterse, F., J.-H. Kim, S. Schouten, D. K. Kristensen, N. N. Koá, and J. S. Sinninghe Damsté (2009a), Constraints on the application of the MBT/CBT palaeothermometer at high latitude environments (Svalbard, Norway), Org. Geochem., 40, 692-699, doi:10.1016/j.orggeochem.2009.03.004.

Peterse, F., S. Schouten, J. van der Meer, M. T. J. van der Meer, and J. S. Sinninghe Damsté (2009b), Distribution of branched tetraether lipids in geothermally heated soils: Implications for the MBT/CBT temperature proxy, Org. Geochem., 40, 201-205, doi:10.1016/j.orggeochem.2008.10.010.

Peterse, F., M. T. J. van der Meer, S. Schouten, G. Jia, J. Ossebaar, J. Blokker, and J. S. Sinninghe Damsté (2009c), Assessment of soil $\mathrm{n}$-alkane $\delta \mathrm{D}$ and branched tetraether membrane lipid distributions as tools for paleoelevation reconstruction, Biogeosciences, 6, 2799-2807, doi:10.5194/bg-62799-2009.

Rao, V. B., and K. Hada (1990), Characteristics of rainfall over Brazil: Annual variations and connection with the Southern Oscillation, Theor. Appl. Climatol., 15, 995-1010.

Rimington, N. (1999), Depositional History of Sands on the Amazon Fan, Univ. of Wales, Cardiff, U. K.

Roy, R., B. Saugier, and H. A. Mooney (2001), Terrestrial Global Productivity, Academic, San Diego, Calif.

Rueda, G., A. Rosell-Melé, M. Escala, R. Gyllencreutz, and J. Backman (2009), Comparison of instrumental and GDGTbased estimates of sea surface and air temperatures from the Skagerrak, Org. Geochem., 40, 287-291, doi:10.1016/j. orggeochem.2008.10.012.

Salati, E., and C. A. Nobre (1991), Possible climatic impacts of tropical deforestation, Clim.Change, 19, 177-196, doi:10.1007/BF00142225.

Schouten, S., C. Huguet, E. C. Hopmans, and J. S. Sinninghe Damsté (2007), Improved analytical methodology of the TEX86 paleothermometry by high performance liquid chromatography/atmospheric pressure chemical ionization-mass spectrometry, Anal. Chem., 79, 2940-2944, doi:10.1021/ ac062339v

Schouten, S., J. Eldrett, D. R. Greenwood, I. Harding, M. Baas, and J. S. Sinninghe Damsté (2008), Onset of long-term cooling of Greenland near the Eocene-Oligocene boundary as revealed by branched tetraether lipids, Geology, 36, 147-150, doi:10.1130/G24332A.1.

Sinninghe Damsté, J. S., E. C. Hopmans, R. D. Pancost, S. Schouten, and J. A. J. Geenevasen (2000), Newly discovered non-isoprenoid dialkyl diglycerol tetraether lipids in sediments, J. Chem. Soc. Chem. Commun., 17, 1683-1684, doi:10.1039/B004517I.

Sinninghe Damsté, J. S., J. Ossebaar, S. Schouten, and D. Verschuren (2008), Altitudinal shifts in the branched tetraether lipid distribution in soil from Mt. Kilimanjaro (Tanzania): Implications for the MBT/CBT continental palaeothermometer, Org. Geochem., 39, 1072-1076, doi:10.1016/j.orggeochem. 2007.11.011.

Stallard, R. F., and J. E. Edmond (1983), Geochemistry of the Amazon: 2. The influence of the geology and weathering environments on the dissolved load, J. Geophys. Res., 88, 9671-9688, doi:10.1029/JC088iC14p09671.

Stute, M., M. Forster, H. Frischkorn, A. Serejo, C. F. Clark, P. Schloser, W. S. Broeker, and G. Bonani (1995), Cooling of tropical Brazil $\left(5^{\circ} \mathrm{C}\right)$ during the Last Glacial Maximum, Science, 269, 379-383, doi:10.1126/science.269.5222.379.

Thompson, L. G., E. Mosleythompson, M. E. Davis, P. N. Lin, K. A. Henderson, J. Coledai, J. F. Bolzan, and K. B. Liu (1995), Late-glacial stage and Holocene tropical ice core records from Huascaran, Peru, Science, 269, 46-50, doi:10.1126/science.269.5220.46.

Thompson, R., and F. Oldfield (1986), Environmental Magnetism, Allen and Unwin, London. 
Traverse, A. (1989), Paleopalynology, 600 pp., Unwin Hyman, Boston, Mass.

van der Hammen, T., and H. Hooghiemstra (2000), Neogene and Quaternary history of vegetation, climate, and plant diversity in Amazonia, Quat. Sci. Rev., 19, 725-742, doi:10.1016/S0277-3791(99)00024-4.

Weijers, J. W. H., S. Schouten, E. C. Hopmans, J. A. J. Geenevasen, O. R. P. David, J. M. Coleman, R. D. Pancost, and J. S. Sinninghe Damsté (2006a), Membrane lipids of mesophilic anaerobic bacteria thriving in peats have typical archaeal traits, Environ. Microbiol., 8, 648-657, doi:10.1111/j.1462-2920.2005.00941.x.

Weijers, J. W. H., S. Schouten, O. C. Spaargaren, and J. S. Sinninghe Damsté (2006b), Occurrence and distribution of tetraether membrane lipids in soils: Implications for the use of the TEX86 proxy and the BIT index, Org. Geochem., 37, 1680-1693, doi:10.1016/j.orggeochem.2006.07.018.

Weijers, J. W. H., E. Schefuss, S. Schouten, and J. S. Sinninghe Damsté (2007a), Coupled thermal and hydrological evolution of tropical Africa over the last deglaciation, Science, 315, 1701-1704, doi:10.1126/science.1138131.

Weijers, J. W. H., S. Schouten, J. C. van den Donker, E. C. Hopmans, and J. S. Sinninghe Damsté (2007b), Environmental controls on bacterial tetraether membrane lipid distribution in soils, Geochim. Cosmochim. Acta, 71, 703-713, doi:10.1016/j.gca.2006.10.003

Willis, K. J., and J. C. McElwain (2002), The Evolution of Plants, Oxford Univ. Press, Oxford, U. K. 